\title{
Deletion of Superoxide Dismutase 1 Blunted Inflammatory Aortic Remodeling in Hypertensive Mice under Angiotensin II Infusion
}

\author{
Yasunaga Shiraishi ${ }^{1, *}$, Norio Ishigami ${ }^{2}$, Takehiko Kujiraoka ${ }^{2}$, Atsushi Sato ${ }^{2}$, Masanori Fujita ${ }^{1}$, Yasuo Ido ${ }^{2}$ \\ and Takeshi Adachi ${ }^{2}$ \\ 1 Division of Environmental Medicine, National Defense Medical College Research Institute, 3-2 Namiki, \\ Tokorozawa Saitama 359-8513, Japan; fujitama@ndmc.ac.jp \\ 2 Department of Internal Medicine, Division of Cardiovascular Medicine, National Defense Medical College, \\ 3-2 Namiki, Tokorozawa Saitama 359-8513, Japan; ishigaminoriohome@yahoo.co.jp (N.I.); \\ nbqnx536@ybb.ne.jp (T.K.); atsushi19821005@yahoo.co.jp (A.S.); yido@bu.edu (Y.I.); \\ tadachi@ndmc.ac.jp (T.A.) \\ * Correspondence: sirayasu10@ndmc.ac.jp; Tel.: +81-4-2995-1626
}

check for updates

Citation: Shiraishi, Y.; Ishigami, N.; Kujiraoka, T.; Sato, A.; Fujita, M.; Ido, Y.; Adachi, T. Deletion of Superoxide Dismutase 1 Blunted Inflammatory Aortic Remodeling in Hypertensive Mice under Angiotensin II Infusion Antioxidants 2021, 10, 471. https:// doi.org/10.3390/antiox10030471

Received: 30 January 2021

Accepted: 15 March 2021

Published: 16 March 2021

Publisher's Note: MDPI stays neutral with regard to jurisdictional claims in published maps and institutional affiliations.

Copyright: (c) 2021 by the authors. Licensee MDPI, Basel, Switzerland. This article is an open access article distributed under the terms and conditions of the Creative Commons Attribution (CC BY) license (https:/ / creativecommons.org/licenses/by/ $4.0 /)$.

\begin{abstract}
Superoxide dismutase (SOD) is an enzyme that catalyzes the dismutation of two superoxide anions $\left(\mathrm{O}_{2}{ }^{-}\right)$into hydrogen peroxide $\left(\mathrm{H}_{2} \mathrm{O}_{2}\right)$ and oxygen $\left(\mathrm{O}_{2}\right)$ and is generally known to protect against oxidative stress. Angiotensin II (AngII) causes vascular hypertrophic remodeling which is associated with $\mathrm{H}_{2} \mathrm{O}_{2}$ generation. The aim of this study is to investigate the role of cytosolic SOD (SOD1) in AngII-induced vascular hypertrophy. We employed C57/BL6 mice (WT) and SOD1 deficient mice (SOD1 ${ }^{-/-}$) with the same background. They received a continuous infusion of saline or AngII (3.2 mg/kg/day) for seven days. The blood pressures were equally elevated at 1.5 times with AngII, however, vascular hypertrophy was blunted in SOD1 ${ }^{-/-}$mice compared to WT mice (WT mice $91.9 \pm 1.13 \mu \mathrm{m}$ versus SOD1 ${ }^{-/-}$mice $68.4 \pm 1.41 \mu \mathrm{m} p<0.001$ ). The elevation of aortic interleukin 6 (IL-6) and phosphorylation of pro-inflammatory STAT3 due to AngII were also blunted in SOD1 ${ }^{-/}$mice's aortas. In cultured rat vascular smooth muscle cells (VSMCs), reducing expression of SOD1 with siRNA decreased AngII induced IL-6 release as well as phosphorylation of STAT3. Pre-incubation with polyethylene glycol (PEG)-catalase also attenuated phosphorylation of STAT3 due to AngII. These results indicate that SOD1 in VSMCs plays a role in vascular hypertrophy due to increased inflammation caused by AngII, probably via the production of cytosolic $\mathrm{H}_{2} \mathrm{O}_{2}$.
\end{abstract}

Keywords: superoxide dismutase 1; angiotensin II; vascular hypertrophy; inflammation; hydrogen peroxide; interleukin 6; STAT3

\section{Introduction}

In our bodies, the reactive oxygen species (ROSs) are constantly produced, and they are high reactivity which potentially damages the biological systems. However, an appropriate amount of ROSs is necessary for biological processes including cell signaling [1,2] and defense system. In normal condition, the proper balance of pro-oxidant-antioxidant system maintains biological homeostasis [3]. Perturbing this balance leads to oxidative stress and causes many disorders including vascular diseases.

Angiotensin II (AngII) is the established pathophysiology of hypertension and vascular hypertrophy. Part of this pathophysiology is caused by ROSs produced by NADPH oxidase (NOX) [4,5]. NOX is activated by AngII through protein kinase C (short term), Rac [6] and c-Src-dependent pathways which stimulate p47phox phosphorylation and translocation [7]. NOX family enzymes (NOX 1,2,4) increase superoxide anion $\left(\mathrm{O}_{2}{ }^{-}\right)$or hydrogen peroxide $\left(\mathrm{H}_{2} \mathrm{O}_{2}\right)$ levels in the vascular smooth muscle cell (VSMC) [8] immediately after AngII binding ( 1 min), which last for $24 \mathrm{~h}[9,10]$. Some NOXs localize at specific subcellular compartments such as caveolae and endosomes [11] and the produced $\mathrm{O}_{2}{ }^{-}$ 
moves through anion chloride channel (CLC-3) [12] and $\mathrm{H}_{2} \mathrm{O}_{2}$ diffuses through aquaporin channels, which changes local oxidation state.

$\mathrm{O}_{2}{ }^{--}$is slowly dismutated to $\mathrm{H}_{2} \mathrm{O}_{2}$ spontaneously (rate constant $=8 \times 10^{4} / \mathrm{mol} / \mathrm{s}$ ). In the presence of nitric oxide $\left(\mathrm{NO}^{-}\right), \mathrm{O}_{2}^{-}$quickly reacts with $\mathrm{NO}^{-}$to form nitrogen peroxide acid $\left(\mathrm{OONO}^{-}\right)$(rate constant $\left.=4-16 \times 10^{9} / \mathrm{mol} / \mathrm{s}\right)$. NO. functions as a vasodilator and vascular protector, however, $\mathrm{OONO}^{-}$does not induce vasodilation and further causes organ damage because of its strong reactivity. Superoxide dismutase (SOD) is one of the antioxidant systems and could rapidly catalyze two $\mathrm{O}_{2}{ }^{--}$into $\mathrm{H}_{2} \mathrm{O}_{2}$ and $\mathrm{O}_{2}$ (rate constant $=2 \times 10^{9} / \mathrm{mol} / \mathrm{s}$ ). The resulting $\mathrm{H}_{2} \mathrm{O}_{2}$ serves as a substrate for catalases, which ultimately break it down into harmless $\mathrm{H}_{2} \mathrm{O}$ and $\mathrm{O}_{2}$ [13]. Therefore, elimination of $\mathrm{O}_{2}{ }^{--}$ by SOD protects from producing $\mathrm{OONO}^{-}$and is likely to relax vascular tension which is related to blood pressure [14] and protect vascular damage. On the other hand, $\mathrm{H}_{2} \mathrm{O}_{2}$ produced by SOD plays a role in signal pathways activated with AngII, which leads to protein and DNA synthesis in VSMCs in vitro $[15,16]$ and excessive production of $\mathrm{H}_{2} \mathrm{O}_{2}$ causes aortic VSMC hypertrophy [17,18]. AngII induces ROSs production and SOD would change the ratio of $\mathrm{O}_{2}{ }^{--}$and $\mathrm{H}_{2} \mathrm{O}_{2}$ local concentration. In other words, SOD helps to relax vascular tension and protect from vascular damage by eliminating $\mathrm{O}_{2}{ }^{--}$; however, the $\mathrm{H}_{2} \mathrm{O}_{2}$ produced by SOD would therefore be an important mediator for AngII-induced vascular hypertrophy. SOD may have both positive and negative effects on vascular pathophysiology.

SOD is a metal-containing enzyme, and the catalytic reaction is performed by cyclic oxidation and reduction of metal ions. There are three main types of SOD: copper/zinccontaining SOD (CuZnSOD), iron-containing SOD (FeSOD), and manganese-containing SOD (MnSOD). SOD genes have been relatively preserved during evolution [13], but their localization and types have changed. As for CuZnSOD, it is found in the periplasmic space in Gram-negative bacteria, but in animals, it is present as a dimer in the cells (SOD1) and in the nucleus, mitochondrial intermembrane space and peroxisomes in addition to the cytoplasm [19]. Extracellular CuZnSOD (SOD3) is present in a tetrameric state extracellularly attached to heparan sulfate proteoglycans. SOD1 and SOD3 are regulated by separate genes; $\mathrm{SOD} 3$ is related to fungal CuZnSOD and may be a more classical form than SOD1.

The SOD of primitive organisms was FeSOD, but it is thought to have fallen out of use with the rise in atmospheric $\mathrm{O}_{2}$, and now FeSOD is absent in animals and fungi, and only present in chloroplasts in plants. Instead, MnSOD was used during evolution, and FeSOD and MnSOD have similar structures [19]. In plants and animals, MnSOD (SOD2) is present in the mitochondrial matrix in a tetrameric state.

Because of the cytosolic location, SOD1 could be important to cell biology. We aimed to investigate the effects of SOD1 in vascular pathophysiology, which changed the local oxidate state in vivo. To date, some studies reported the role of SOD1 in blood pressure and vascular pathophysiology, however, the result was inconsistent and controversial [20-24]. The involvement of local $\mathrm{H}_{2} \mathrm{O}_{2}$ in AngII-induced aortic hypertrophy has not yet been completely elucidated in vivo.

In the present in vivo study, we hypothesized that SOD1 exerts its effects on vascular pathology by altering the local oxidative state in vivo and aimed to investigate its effects. We employed SOD1 deficient mice (SOD1 ${ }^{-/}{ }^{-}$) and compared them with wild-type mice (WT). Without any intervention, there was no difference in blood pressure and aortic pathology. By infusing a relatively high dose of AngII ( $3.2 \mathrm{mg} / \mathrm{kg} /$ day) for 1 week, although the response to AngII-induced hypertension was comparable, the aortic hypertrophy was blunted in $\mathrm{SOD}^{-/-}$mice compared with WT mice.

\section{Materials and Methods}

\subsection{Experimental Animals}

Male SOD1 $1^{-/-}$mice were obtained from Jackson Laboratory (Bar Harbor, Maine). These mice were backcrossed to C57BL/6J strain mice for 8 generations as we did pre- 
viously [25]. Next, we interbred heterozygous $\mathrm{SOD}^{+/-}$mice to obtain wild-type (WT) mice and homozygous SOD1 $1^{-/-}$mice within the same litter. Animals were maintained in a temperature-controlled facility on a $12 \mathrm{~h}$ light/dark cycle (lights on from 7:00 a.m. to 7:00 p.m.) and fed freely with a normal chow diet (CLEA Japan, Inc., Higashiyama, Meguro-ku, Tokyo) and water. The genotype of each mouse was checked by polymerase chain reaction on DNA isolated from a tail or ear biopsy samples using the following primers:

WT 5'-TGAACCAGTTGTGTTGTCAGG-3'

WT 5'- TCCATCACTGGTCACTAGCC-3'

Mutant $5^{\prime}$ - TGTTCTCCTCTTCCTCATCTCC- $3^{\prime}$

Mutant $5^{\prime}$ - ACCCTTTCCAAATCCTCAGC- $3^{\prime}$

All experimental protocols were approved by National Defense Medical College Board for Studies in Experimental Animals (approval number: 10063).

\subsection{AngII Infusion}

We implanted 12- to 16-week-old male mice with osmotic mini-pumps (Alzet model 1007D; DURECT Corp, Cupertino, CA) containing AngII (A9525 Sigma-Aldrich Corp, St. Louis, MO, USA) or saline ( $n=22 \sim 26$ per group). The delivery rate of AngII was $3.2 \mathrm{mg} / \mathrm{kg} /$ day for seven days as in the study of Wang HD et al. [26]. All surgical procedures in this experiment were performed by aseptic manipulation, and disinfectant solution ( $10 \%$ povidone-iodine solution, Meiji Co., Ltd., Tokyo, Japan) was used. Mice were sedated in an anesthesia box filled with $3.5 \%$ sevoflurane. Then, under continuous inhalation of $2.5 \%$ to $3.5 \%$ sevoflurane, we made a mid-scapular skin incision with surgical scissors and fine forceps to make a small pocket and placed an osmotic mini-pump inside. The wound was sutured with silk thread. $5 \mathrm{mg} / \mathrm{kg}$ of meloxicam was injected subcutaneously as an analgesic.

\subsection{VSMC Cell Culture}

We obtained 6-week-old male Wistar rats from CLEA Japan, Inc. (Tokyo, Japan). All surgical procedures in this experiment were performed by aseptic manipulation, and disinfectant solution ( $10 \%$ povidone-iodine solution, Meiji Co., Ltd., Tokyo, Japan) was used. Rats were sedated in an anesthesia box filled with $5 \%$ sevoflurane. After sufficiently deep anesthesia was obtained, the rats were sacrificed to death by cervical dislocation. Saline reflux was performed from the heart, and the thoracic aorta was removed. After cleaning up the fat tissue around the aorta, the aorta was cut longitudinally and opened. Then the media was peeled off from the adventitia. The isolated media was cut into small pieces and incubated with $0.75 \mathrm{mg} / \mathrm{mL}$ collagenase and $0.125 \mathrm{mg} / \mathrm{mL}$ elastase for $30 \mathrm{~min}$ to $60 \mathrm{~min}$ by pipetting to disperse the cells. The collected cells were grown in $1.0 \mathrm{~g} / \mathrm{L}$ glucose Dulbecco's modified Eagle's medium (\#11885 Life Technologies Japan Ltd. Tokyo, Japan) with $10 \%$ FBS and penicillin/streptomycin. To decrease expression of SOD1, we incubated VSMCs with SOD1 siRNA (\#1330003 (set of 3 Oligos; Oligo IDs: RSS303072, RSS303073, RSS303074) Invitrogen) and Lipofectamine RNAiMAX (Invitrogen) for $72 \mathrm{~h}$, and after changing the medium to $0.1 \%$ FBS and leaving for $24-48 \mathrm{~h}$, performed experiments with or without AngII or Interleukin-6 (IL-6). To inhibit SOD1 activity pharmacologically, we used DETC (diethyldithiocarbamate) which was a copper-chelating compound. $0.1 \mathrm{mM}$ DETC was added to VSMC culture fluid $4 \mathrm{~h}$ before the addition of AngII. Catalase was administered $24 \mathrm{~h}$ before AngII administration. We used polyethylene glycol-conjugated catalase (PEG-catalase) (C4963 Sigma-Aldrich Corp, St. Louis, MO. USA). It is expected to be highly stable while maintaining good reactivity by binding polyethylene glycol to catalase [27].

\subsection{Measurement of SOD Activity}

SOD activities in red blood cells were determined using SOD Assay Kit (\#43379000 Wako Pure Chemical Industries, Ltd. Osaka, Japan) following the kit's instructions. The 
erythrocytes were washed three times with $0.9 \% \mathrm{NaCl}$. The washed erythrocytes $(0.1 \mathrm{~mL})$ were lysed using distilled water $(0.5 \mathrm{~mL})$ and mixed. To remove the hemoglobin, $1.2 \mathrm{~mL}$ of an ethanol/chloroform $(1: 1 \mathrm{v} / \mathrm{v})$ mixture was added to an aliquot $(0.6 \mathrm{~mL})$ of hemolysate. After centrifugation for $10 \mathrm{~min}$ at $1600 \times g$, the supernatant was collected for SOD assay. This kit uses the nitro blue tetrazolium (NBT) method to measure SOD activity. $\mathrm{O}_{2}{ }^{\cdot-}$ produced by the addition of xanthine oxidase $(\mathrm{XO})$ reduces NBT to form nitroblue tetrazolium diformazan, which shows absorbance at $560 \mathrm{~nm}$ and the absorbance was measured by the plate reader (iMark ${ }^{\mathrm{TM}}$ Microplate Absorbance Reader, BIO-RAD, Hercules, CA, USA). In the presence of SOD, some of $\mathrm{O}_{2}{ }^{--}$is dismutated to $\mathrm{H}_{2} \mathrm{O}_{2}$ and $\mathrm{O}_{2}$, inhibiting the formation of diformazan. The SOD activity in a sample is measured by its inhibition rate as shown in Equation (1) [28].

SOD activity $($ Inhibition rate $\%)=\left(\left(\mathrm{Abs}_{\mathrm{BL}}-\mathrm{Abs}_{\mathrm{BLBL}}\right)-\left(\mathrm{Abs}_{\mathrm{S}}-\mathrm{Abs}_{\mathrm{SBL}}\right)\right) /\left(\mathrm{Abs}_{\mathrm{BL}}-\mathrm{Abs}_{\mathrm{BL} \mathrm{BL}}\right) * 100$

Abs ${ }_{\mathrm{BL}}$ : Absorbance of the blind test (water)

Abs BLBL: Absorbance of reagent blind test (water without XO)

Abs $\mathrm{S}$ : Absorbance of sample test

Abs SBL: Absorbance of sample blind test (sample without XO)

\subsection{Measurement of Blood Pressure}

Systolic blood pressure was measured by the tail-cuff method (MK-2000; Muromachi Kikai Co., Ltd. Tokyo, Japan) without anesthesia between 6:00 a.m. and 8:00 a.m., following the instructions as previous reports $[20,22,26]$. To reduce the stress associated with the $\mathrm{BP}$ measurements, mice were introduced into the plastic restrainer and measured BP from one week before the main experiment and 10 times averages were calculated at each determination.

\subsection{Tissue Preparation and Histology}

The mice were deeply anesthetized and perfused with $0.9 \%$ saline from the left ventricular apex, followed by perfusion fixation with $4 \%$ paraformaldehyde. Aortas were fixed in $10 \%$ formalin for $48 \mathrm{~h}$. The $2 \mathrm{~mm}$ thoracic aorta rings were cut off at $4 \mathrm{~mm}$ from the aortic arch and embedded in paraffin. These were sectioned (4- $\mu \mathrm{m}$ thickness) and stained with hematoxylin and eosin (HE). For immunohistochemistry, SOD1 was visualized with anti-human SOD1 polyclonal antibodies (Enzo Life Sciences, Inc., Farmingdale, NY, USA) using a Vectastain Elite ABC kit (Vector Laboratories, Burlingame, CA, USA) with diamino-benzidine as the substrate, following the instructions.

\subsection{Measurement of Aorta Medial Area}

We cut out the aorta ring $5 \mathrm{~mm}$ from the aortic arch and measured the thoracic aorta medial area using a HE Stain; Elastica van Gieson (EVG) stain, and Masson's trichrome (Masson's) stained cross-section slides. The media was defined as the area between the internal and external elastic lamina. For each mouse, the average of ten consecutive crosssections was measured and quantified using the NIH Image software (National Institutes of Health, public domain software, Bethesda, MD, USA).

\subsection{Measurement of Extracellular and Intracellular $\mathrm{H}_{2} \mathrm{O}_{2}$ Levels}

We measured the serum derivatives of reactive oxygen metabolites (d-ROMs) using FREE carpe diem (Diacron International s.r.l. Grosseto, Italy) as an extracellular $\mathrm{H}_{2} \mathrm{O}_{2}$ indicator. The serum d-ROMs test detects hydro-peroxide $(\mathrm{R}-\mathrm{OOH})$ and measurements are expressed as Carratelli units (CARR U), with 1 CARR U corresponding to $0.08 \mathrm{mg} / \mathrm{dL}$ $\mathrm{H}_{2} \mathrm{O}_{2}$. Oxidized glutathione (GSSG) levels and reduced glutathione (GSH) levels were measured in red blood cells as an intracellular $\mathrm{H}_{2} \mathrm{O}_{2}$ indicator using GSH/GSSG Kit (Oxis International Inc., Foster City, CA, USA), following the instructions. 
Superoxide productions in aortic tissue were visualized by dihydroxyethidine (DHE) staining of aortic frozen samples. Vascular GSH/GSSG ratios were assessed with CoulArray ${ }^{\circledR}$ detector (\#5600A, ESA Inc., Chelmsford, MA, USA) after TCA extraction [29].

\subsection{Western Blotting}

Aortas were homogenized with a glass-glass homogenizer on ice and dissolved in homogenization buffer (Tris-HCl $20 \mathrm{mmol} / \mathrm{L}, \mathrm{pH} 7.4, \mathrm{NaCl} 150 \mathrm{mmol} / \mathrm{L}, \mathrm{Na}_{2}$ EDTA $1 \mathrm{mmol} / \mathrm{L}$, EGTA $1 \mathrm{mmol} / \mathrm{L}, 1 \% \mathrm{NP}-40$, sodium pyrophosphate $2.5 \mathrm{mmol} / \mathrm{L}$, beta-glycerophosphate $1 \mathrm{mmol} / \mathrm{L}, \mathrm{Na}_{2} \mathrm{VO}_{4} 1 \mathrm{mmol} / \mathrm{L}$ ) supplemented with PMSF $1 \mathrm{mmol} / \mathrm{L}$ and protease inhibitor cocktail (Sigma-Aldrich Corp, St. Louis, MO, USA). VSMCs were dissolved in homogenization buffer and collected with a scraper. After brief sonication (10 s, $\times 3$, on ice), these samples were centrifuged at $10,000 \times g$ for $10 \mathrm{~min}$ at $4{ }^{\circ} \mathrm{C}$. Protein concentrations were assessed by the Bradford assay with BSA as a standard. Aortic and VSMCs lysates were resolved by SDS-PAGE and transferred to PVDF membranes ( $30 \mathrm{~V}, 135 \mathrm{~min}$ ). The membranes were incubated with the following antibodies overnight at 1:1000 dilution: SOD1 (Enzo Life Sciences, Inc., Farmingdale, NY, USA), SOD2 (Assay Designs, Inc., Ann Arbor, MI, USA), Phospho-STAT3 (Cell Signaling Technologies, Danvers, MA, USA), STAT3 (Cell Signaling Technologies, Danvers, MA, USA), Phospho-ERK1/2 (Cell Signaling Technologies, Danvers, MA, USA), ERK1/2 (Cell Signaling Technologies, Danvers, MA, USA), PhosphoAkt (Cell Signaling Technologies, Danvers, MA, USA), Akt (Cell Signaling Technologies, Danvers, MA, USA) and GAPDH (Cell Signaling Technologies, Danvers, MA, USA). They were then incubated with peroxidase-conjugated anti-mouse or anti-rabbit antibodies (Cell Signaling Technologies, Danvers, MA, USA) overnight. The specific protein amount was detected after immersing in Enhanced Chemiluminescence (ECL) (Thermo Fisher Scientific Inc., Waltham, MA, USA) and light emission was detected and captured by a LAS-3000 Imager (Fujifilm, Tokyo, Japan).

\subsection{Quantitative Real-Time PCR}

Total RNA was isolated from the aortas using TRI reagent (Sigma-Aldrich Corp, St. Louis, MO, USA). cDNA was synthesized using SuperScript III reverse transcriptase (Thermo Fisher Scientific Inc., Waltham, MA, USA) according to the manufacturer's protocol. mRNA expression was assessed quantitatively by real-time PCR with Power SYBR Green PCR Master Mix (Thermo Fisher Scientific Inc., Waltham, MA, USA). Samples were run in duplicate on the ABI PRISM 7700 (Thermo Fisher Scientific Inc., Waltham, MA, USA). The following oligonucleotide primer pairs were used (Table 1).

Table 1. Primer pairs for quantitative real-time PCR.

\begin{tabular}{|c|c|c|c|}
\hline Gene & & Sequence & Product Suze (bp) \\
\hline Il6 (IL-6) & $\begin{array}{l}\text { Forward: } \\
\text { Reverse: }\end{array}$ & $\begin{array}{c}\text { 5'-ACAACCACGGCCTTCCCTACTT-3' } \\
5^{\prime} \text {-CACGATTTCCCAGAGAACATGTG-3' }\end{array}$ & 129 \\
\hline $\mathrm{Ccl} 2(\mathrm{MCP}-1)$ & $\begin{array}{l}\text { Forward: } \\
\text { Reverse: }\end{array}$ & $\begin{array}{c}\text { 5'-CCACTCACCTGCTGCTACTCAT-3' } \\
5^{\prime} \text {-TGGTGATCCTCTTGTAGCTCTCC-3' }\end{array}$ & 76 \\
\hline Il1b (IL-1beta) & $\begin{array}{l}\text { Forward: } \\
\text { Reverse: }\end{array}$ & $\begin{array}{l}\text { 5'-GCTGCTTCCAAACCTTTGAC-3' } \\
5^{\prime} \text {-TTCTCCACAGCCACAATGAG-3' }\end{array}$ & 118 \\
\hline Nox1 & $\begin{array}{l}\text { Forward: } \\
\text { Reverse: }\end{array}$ & $\begin{array}{l}\text { 5'-CTACAGAAGAAGCCAACAGGCCAT-3' } \\
5^{\prime} \text {-ACTGTCATGTTTGGAGACTGGATG-3' }\end{array}$ & 117 \\
\hline Cybb (Nox2) & $\begin{array}{l}\text { Forward: } \\
\text { Reverse: }\end{array}$ & $\begin{array}{l}5^{\prime} \text {-CCCTTTGGTACAGCCAGTGAAGAT-3' } \\
5^{\prime} \text {-CAATCCCGGCTCCCACTAACATCA-3' }\end{array}$ & 67 \\
\hline Nox4 & $\begin{array}{l}\text { Forward: } \\
\text { Reverse: }\end{array}$ & $\begin{array}{l}\text { 5'-GGATCACAGAAGGTCCCTAGCAG-3' }^{\prime} \\
5^{\prime} \text {-GCGGCTACATGCACACCTGAGAA-3' }\end{array}$ & 113 \\
\hline Rn18s (18S rRNA) & $\begin{array}{l}\text { Forward: } \\
\text { Reverse: }\end{array}$ & $\begin{array}{c}\text { 5'-TTCCGATAACGAACGAGACTCT-3' } \\
5^{\prime} \text {-TGGCTGAACGCCACTTGTC-3 }\end{array}$ & 99 \\
\hline
\end{tabular}




\section{Results \\ 3.1. Baseline Characteristics and Blood Pressure}

We confirmed that SOD1 was deficient in aortas from SOD1 ${ }^{-/-}$mice by immunohistochemistry and western blot analysis as previously reported [25]. SOD2 expression was comparable in the aorta of WT and SOD1 ${ }^{-/-}$mice (Figure 1A). SOD activity in red blood cells was markedly decreased in SOD1 ${ }^{-/}$- mice (WT mice $59.1 \pm 2.9$ versus SOD $1^{-/-}$mice $17.9 \pm 2.0(n=22-26))$ (Figure $1 B)$, although plasma SOD activity was similar. (Figure $1 C$ ). SOD activity remained in SOD1 ${ }^{-/-}$erythrocytes. This may be a result of the spontaneous dismutation of $\mathrm{O}_{2}{ }^{-}$or the residual SOD3 activity of the samples. The baseline systolic blood pressure was similar between groups (WT mice $98.3 \pm 2.0 \mathrm{mmHg}(n=12)$ versus SOD1 ${ }^{-/-}$mice $\left.98.5 \pm 2.1 \mathrm{mmHg}(n=12)\right)$. AngII infusion increased systolic blood pressure similarly and there was no significant difference in blood pressure between the two strains (WT mice $156.6 \pm 2.5 \mathrm{mmHg}(n=12)$ versus SOD1 ${ }^{-/-}$mice $157.3 \pm 4.2 \mathrm{mmHg}(n=12)$ at 7 days) (Figure 1D).

(A)



(B)

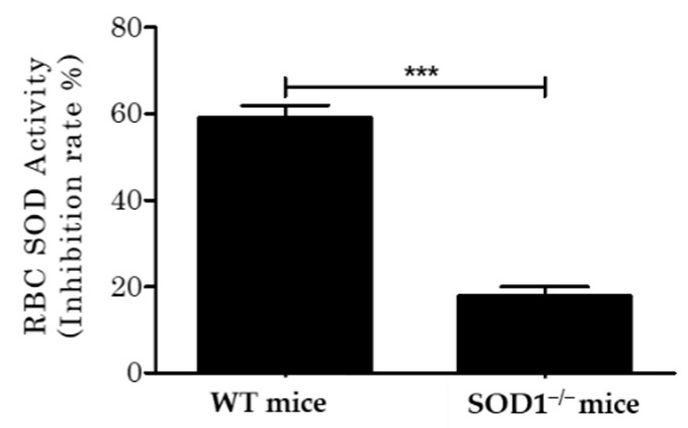

(C)

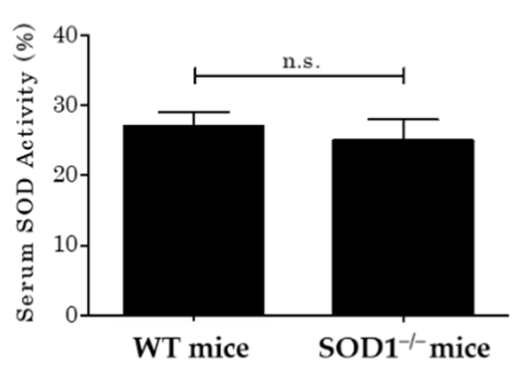

(D)

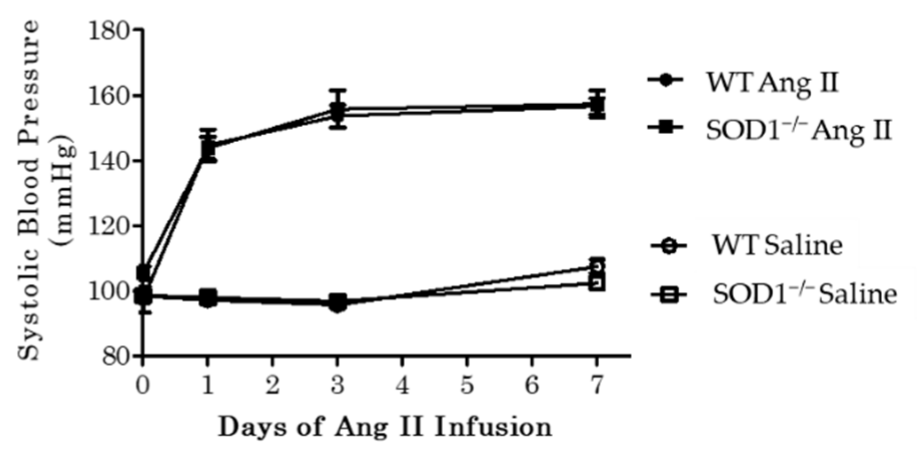

Figure 1. The efficiency of superoxide dismutase (SOD1) deletion and effect of AngII infusion on systolic blood pressure. (A) Immunohistochemistry (upper part) and Western blot analysis (lower part) of aortas from WT mice and SOD1 ${ }^{-/-}$mice using anti-SOD1 antibodies. (Scale bars $=100 \mu \mathrm{m}$.) SOD activity in red blood cells (B) and serum (C). Red blood cells (RBCs) do not have mitochondria so SOD activity would be that of cytosol SOD (SOD1). ( $n=22 \sim 26$ per group. ${ }^{* * *} p<0.001$ n.s.: not significant). (D) Saline or AngII (3.2 mg/kg per day) was chronically infused using osmotic mini-pumps. Systolic blood pressure was measured by the tail-cuff method ( $n=12$ per group). Error bars represent SEM. WT: wild type; SOD1 ${ }^{-/-}$: superoxide dismutase 1 deficient; AngII: angiotensin II.

\subsection{Histological and Morphometric Analysis}

The collected aortas were subjected to HE staining, EVG staining, and Masson's trichrome staining (Figure 2A) (Supplemental Figure S1). In the saline-treated group, no changes were observed in SOD1 $1^{-/}$mice compared to WT mice, while AngII-treated mice showed hypertrophy of vascular smooth muscle cells with associated thickening of 
the tunica media and thickening of the adventitia due to fibrosis. Nuclei were enlarged, nuclear staining by hematoxylin was weakened, and cytoplasmic vacuolation was observed, suggesting that cell death occurred. The above findings with AngII administration were more pronounced in WT but were attenuated in SOD1 ${ }^{-/-}$. Quantitative analysis of aortic vessel wall thickness showed that Ang II-induced aortic wall thickening, which was observed in WT, was attenuated in SOD1 ${ }^{-/-}$(Figure $2 \mathrm{~B}$,) (WT mice $91.9 \pm 1.13 \mu \mathrm{m}$ versus SOD1 ${ }^{-/-}$mice $\left.68.4 \pm 1.41 \mu \mathrm{m} p<0.001\right)$. Vascular tunica media area was also weakened in SOD1 ${ }^{-/-}$(WT mice $0.223 \pm 0.0051 \mathrm{~mm}^{2}$ versus SOD1 ${ }^{-/-}$mice $0.186 \pm 0.004 \mathrm{~mm}^{2}$ $p=0.001$ ) (Figure 2C).

(A)

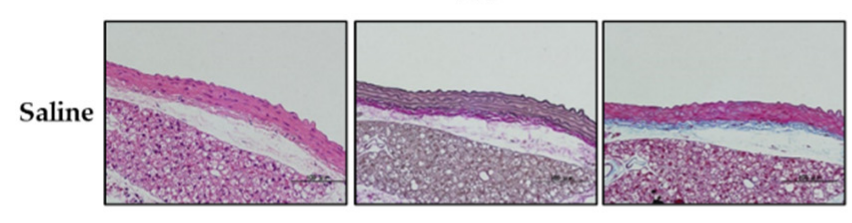



HE

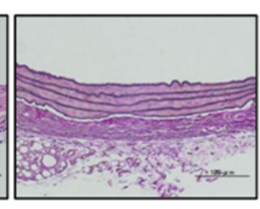

EVG

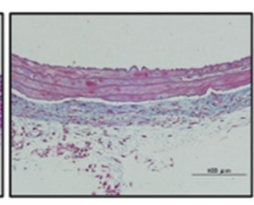

Masson's

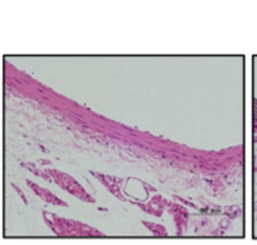

SOD1 $^{-1-}$

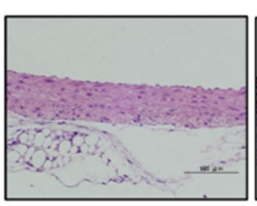

HE

(C)
(B)



Saline Ang II
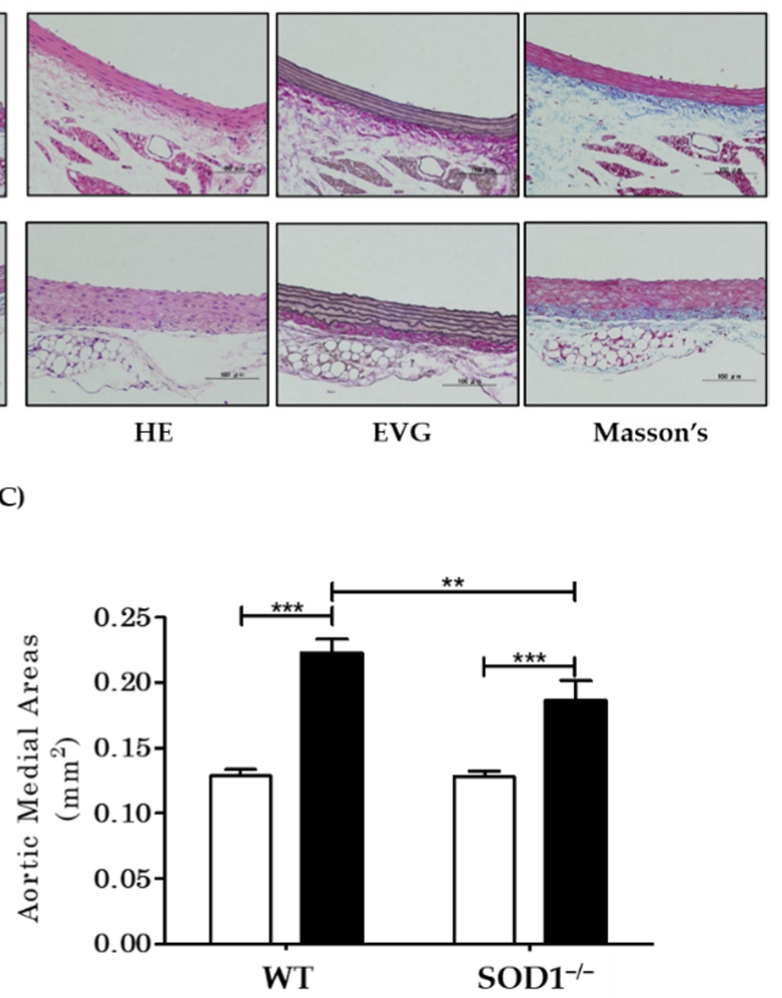

Figure 2. Microscopic appearance of aortas and quantitative analysis. (A) Hematoxylin-eosin (HE), Elastica van Gieson (EVG), and Masson's staining of aortas. WT mice with saline (upper left), SOD1 ${ }^{-/-}$mice with saline (upper right), WT mice with AngII (lower left), SOD1 ${ }^{-/-}$mice with AngII (lower right). (Scale bar $=100 \mu \mathrm{m}$.) (B) Quantification of aorta wall thickness and (C) medial areas measured by NIH Image software $\left(n=10-12\right.$ per group. $\left.{ }^{* *} p<0.01{ }^{* * *} p<0.001\right)$ Error bars represent SEM. HE: Hematoxylin-Eosin Stain; EVG: Elastica van Gieson stain; Masson's: Masson's trichrome stain.

\subsection{Extracellular and Intracellular $\mathrm{H}_{2} \mathrm{O}_{2}$ Levels In Vivo}

$\mathrm{H}_{2} \mathrm{O}_{2}$ is produced from $\mathrm{O}_{2}{ }^{--}$by SOD and we hypothesized that the intracellular $\mathrm{H}_{2} \mathrm{O}_{2}$ would be specifically low in SOD1 ${ }^{-/-}$mice because SOD1 is localized in the cytosol and the mitochondrial intermembrane space. We measured both the extracellular and intracellular $\mathrm{H}_{2} \mathrm{O}_{2}$ levels in WT and SOD1 ${ }^{-/-}$mice. We used serum d-ROMs levels as an indicator of extracellular $\mathrm{H}_{2} \mathrm{O}_{2}$ levels [30]. The serum d-ROMs test detects hydro-peroxide products ( $\mathrm{R}-\mathrm{OOH}$ ), which reflect serum $\mathrm{H}_{2} \mathrm{O}_{2}$ levels [31]. The serum d-ROMs levels were elevated similarly in both types of mice under AngII infusion (WT mice from $113.7 \pm 5.2$ to $181.5 \pm 6.5 \mathrm{U}$.CARR versus SOD1 ${ }^{-/-}$mice from $108.7 \pm 4.8$ to $164.7 \pm 11.3 \mathrm{U}$.CARR $(n=12))$ (Figure $3 \mathrm{~A})$. 

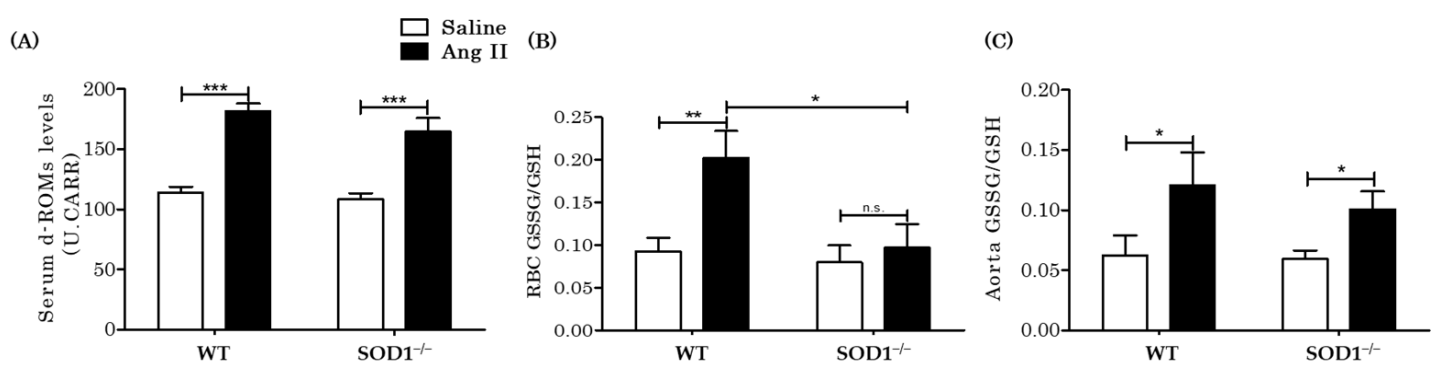

Figure 3. Extracellular and intracellular $\mathrm{H}_{2} \mathrm{O}_{2}$ levels in blood and aortas in vivo. (A) Derivatives of reactive oxygen metabolites (d-ROMs), which detect hydro-peroxide ( $\mathrm{R}-\mathrm{OOH})$, were measured as an extracellular $\mathrm{H}_{2} \mathrm{O}_{2}$ indicator ( $n=12$ per group. $\left.{ }^{* *} p<0.001\right)$. (B) Oxidized glutathione (GSSG)/reduced glutathione (GSH) ratios were measured in RBCs as an indicator of intracellular $\mathrm{H}_{2} \mathrm{O}_{2}\left(n=8\right.$ per group. ${ }^{*} p<0.05^{* *} p<0.01$ n.s.: not significant). (C) GSSG/GSH ratios in aortas $\left(n=10 \sim 11\right.$ per group. $\left.{ }^{*} p<0.05\right)$. Error bars represent SEM. ROS: reactive oxygen species; WT: wild type; SOD1 ${ }^{-/-}$: superoxide dismutase 1 deficient; Ang II: angiotensin II; d-ROMs: derivatives of reactive oxygen metabolites; RBC: red blood cell; GSSG: oxidized glutathione; GSH: reduced glutathione; DHE: Dihydroethidium.

Next, we measured the oxidized glutathione (GSSG) levels and reduced glutathione (GSH) levels in red blood cells as an indicator of cytosolic $\mathrm{H}_{2} \mathrm{O}_{2}$ levels. The $\mathrm{H}_{2} \mathrm{O}_{2}$ in the cytosol is promptly metabolized to $\mathrm{H}_{2} \mathrm{O}$ by catalase, glutathione peroxidase (Gpx), and peroxiredoxins [32]. When Gpx metabolizes $\mathrm{H}_{2} \mathrm{O}_{2}$, it oxidizes GSH to GSSG. An increase in GSSG/GSH ratio thus reflects an increase in intracellular $\mathrm{H}_{2} \mathrm{O}_{2}$ level. GSSG/GSH ratios in red blood cells were increased in WT mice by AngII, while in SOD1 $1^{-/-}$mice, the ratios did not increase (WT mice from $0.093 \pm 0.016$ to $0.20 \pm 0.032$ versus SOD1 $1^{-/-}$mice from $0.080 \pm 0.020$ to $0.097 \pm 0.027(n=8)$ ) (Figure 3B). The GSSG/GSH ratio in the aorta was also assessed: the GSSG/GSH ratio increased with AngII and tended to increase less in SOD1 $1^{-/-}$but did not differ significantly (WT mice from $0.062 \pm 0.017$ to $0.12 \pm 0.027$ versus $\mathrm{SOD}^{-/-}$mice from $0.059 \pm 0.007$ to $0.10 \pm 0.015(n=10-11)$ ) (Figure 3C). We also assessed aortic $\mathrm{O}_{2}{ }^{-}-$levels with the DHE stain. The DHE intensities were significantly increased by AngII in both WT and SOD1 ${ }^{-1}$ mice, and there was no difference between both mice (Supplemental Figure S2). These results were not consistent with that for red blood cells measured above. These discrepancies were thought to be due to the fact that the $\mathrm{O}_{2}{ }^{-}$ produced by Ang II is catalyzed by SOD2, which is mainly localized in the mitochondrial matrix. In the SOD1 $1^{-/-}$mice, SOD2 was still functioning and would hinder detection of SOD1 activity in aortas. As there are no mitochondria in red blood cells, SOD1 activity would have become apparent.

\subsection{Western Blot Analysis for Downstream Signaling of AngII in Aortas In Vivo}

Various studies have indicated that AngII stimulates a series of protein kinases, including ERK1/2, Akt/protein kinase B, and JAK2/STAT3 pathways, leading to cell proliferation in vitro [33-37]. We investigated the expression and phosphorylation of ERK1/2, Akt, and STAT3 in proteins from the aortas in vivo. Unlike previous in vitro studies $[34,36,37]$, the phosphorylation of ERK1/2 and Akt was not augmented by seven days of AngII-infusion in both groups (Figure 4A). On the other hand, AngII-infusion enhanced phosphorylation of STAT3 in the aortas from WT mice, which was blunted in those from SOD1 ${ }^{-1}$ mice (Figure 4A,B). We, therefore, considered phosphorylation of STAT3 to be a mechanism for AngII-induced cell modification in vivo. 


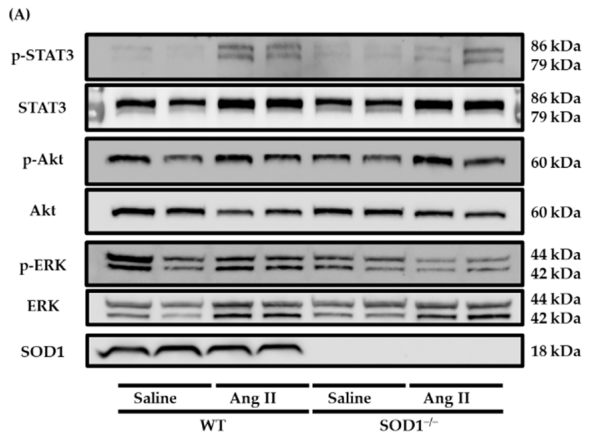

(B)

Figure 4. The protein expressions of aortas from WT and SOD1 ${ }^{-/-}$mice with saline or AngII. (A) Representative results of Western blot analyses of phosphorylated STAT3, phosphorylated Akt, phosphorylated ERK1/2, and SOD1 in aortas from WT and SOD1 ${ }^{-/-}$mice, with saline or AngII. (B) Quantitative analyses by densitometry of immunoblots expressed as ratios of phosphorylated STAT3 to STAT3. ( $n=8$ per group. ${ }^{*} p<0.05$ n.s.: not significant) Error bars represent SEM. STAT3: signal transducer and activator of transcription 3; ERK: extracellular signal-regulated kinase.

\subsection{Serum Inflammatory Cytokines Levels and Aortic mRNA Expressions In Vivo}

STAT3 is phosphorylated by cytokines and IL-6 is representative of cytokines that phosphorylate STAT3. Previous studies [38-40] have shown that Ang II induces IL-6 synthesis in VSMCs and that the reaction requires ROSs from the NOX system [38]. This suggests that IL-6 secreted by the vessel wall may be responsible for the difference in aortic wall changes observed after Ang II administration as described above. Serum IL-6 levels were elevated similarly in both types of mice by AngII infusion (Figure 5A). To investigate aortic local IL-6 levels, we assessed mRNA expression in the aortas from the four groups. AngII upregulated IL- 6 mRNA expression in the aorta of WT mice but suppressed the increase in expression in SOD1 ${ }^{-/-}$mice (Figure 5B). We also examined other inflammatory cytokines. AngII induced expression of IL-1 $\beta$ and MCP-1 mRNA in aortas from WT mice, which was blunted in aortas from SOD1 ${ }^{-1-}$ mice (Figure 5C,D). On the other hand, there were no significant differences in serum TNF- $\alpha$ levels and the expression of TNF- $\alpha$ mRNA in aortas in any of the four experimental groups (Supplemental Figure S3A,B). These data indicated that AngII induced inflammations, however, the local inflammation in the aortas were blunted in SOD $1^{-/-}$mice.

(A)
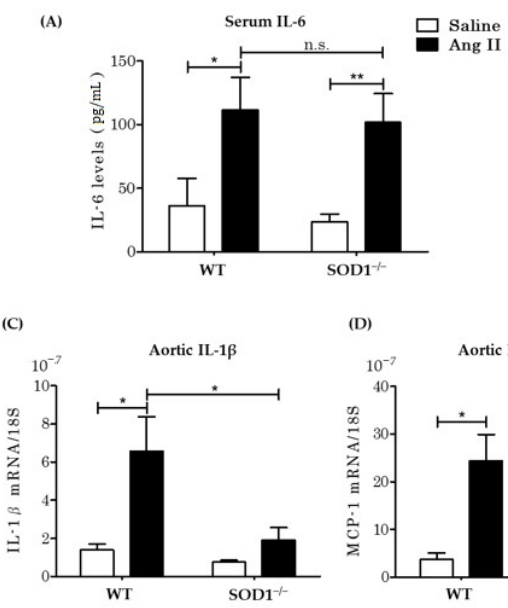

(D)

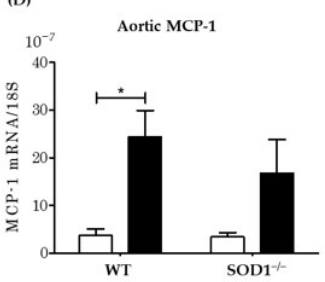

(B)

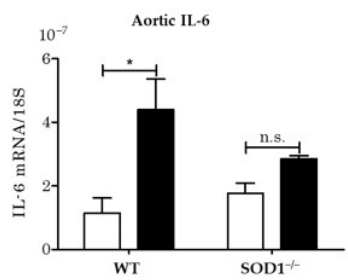

(E)

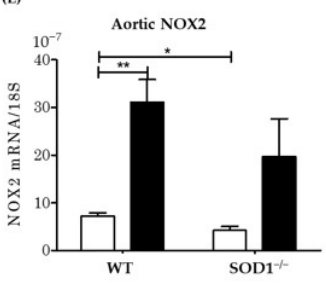

Figure 5. Serum IL-6 concentration and mRNA expression in aortas. (A) Serum IL-6 levels were analyzed by the ELISA test $\left(n=9-10\right.$ per group. ${ }^{*} p<0.05^{* *} p<0.01$ n.s.: not significant). (B-E) The local aortic IL-6 (B), IL-1 $\beta$ (C), MCP-1 (D) and NOX2 (E) levels were detected as mRNA expressions, which were compensated with an internal control: $18 \mathrm{~S}\left(n=4-8\right.$ per group; ${ }^{*} p<0.05,{ }^{* *} p<0.01$ n.s.: not significant). Error bars represent SEM. IL-6: interleukin 6; IL-1 $\beta$ : interleukin 1 $\beta$; MCP-1: Monocyte Chemotactic Protein-1; NOX2: NADPH Oxidase 2. 
As AngII activates NOX family enzymes (NOX 1,2,4) $[9,10]$ in order to produce ROSs, we also assessed the mRNA expressions of NOX1, 2, and 4 in aortas (Figure 5E) (Supplemental Figure S3C,D). AngII increased the expression of NOX2 in aortas from WT mice, but this was blunted in those from SOD1 ${ }^{-1-}$ mice (Figure 5E). This would be related to aortic ROSs production by AngII, which was attenuated in SOD1 ${ }^{-/-}$mice.

\subsection{Rat VSMCs Incubated with AngII}

In the present AngII infusion model, STAT3 was phosphorylated in the aorta in vivo. So, we next examined the phosphorylation of STAT3 by AngII in vitro. We cultured rat VSMCs and incubated them with $100 \mathrm{nM}$ AngII. STAT3 was not activated in a short period of time but its phosphorylation was significantly increased after $24 \mathrm{~h}$ (Figure 6A). This meant that phosphorylation of STAT3 due to AngII required time. We down-regulated SOD1 expression in rat VSMCs using SOD1 siRNA $(6 \mathrm{nM})$. In the control VSMCs, AngII had induced STAT3 phosphorylation at $24 \mathrm{~h}$, though this response was blunted in VSMCs treated with SOD1 siRNA (Figure 6B). VSMCs were also incubated with $0.1 \mathrm{mM}$ diethyldithiocarbamate (DETC) to inhibit the activity of SOD1 pharmacologically. DETC blunted the phosphorylation of STAT3 in incubation with AngII for $24 \mathrm{~h}$ (Figure 6C).$$
\text { (A) }
$$
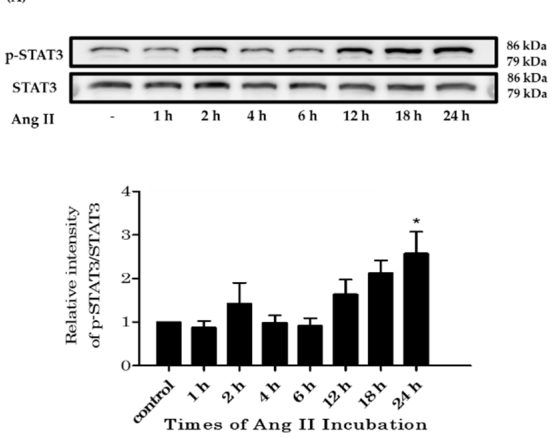

(C)
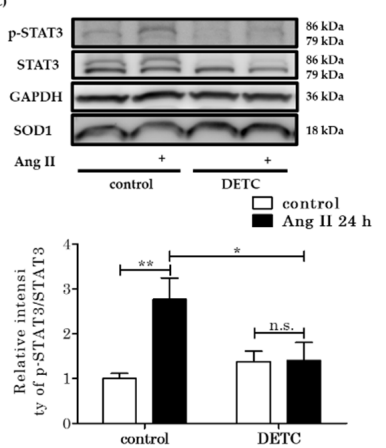

(E)
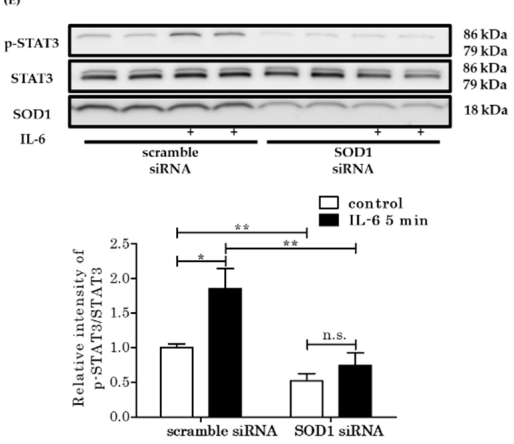
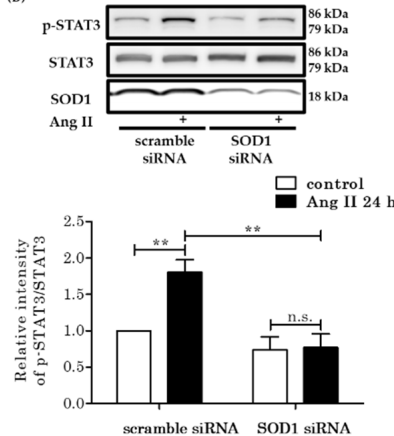

(D)

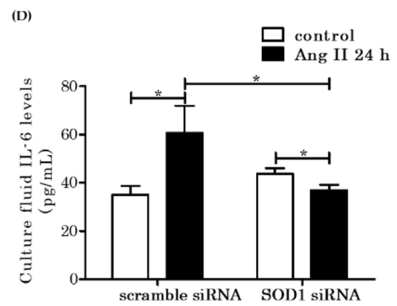

(F)
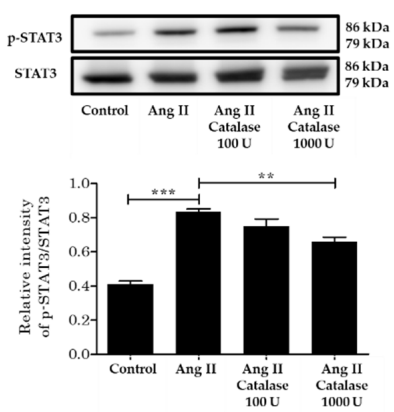

Figure 6. Rat vascular smooth muscle cells (VSMCs) incubated with AngII. (A) Time course of STAT3 phosphorylation of VSMCs due to AngII. VSMCs were stimulated with $100 \mathrm{nM}$ AngII for the indicated 
times. The top panels are representative immunoblots for Ang II-induced phosphorylation of STAT3. The bottom panels represent averaged data quantified by densitometry of immunoblots, expressed as fold increases in phosphorylation, in which the phosphorylation for the control was defined as $1.0\left(n=4\right.$ per group. $\left.{ }^{*} p<0.05\right)(\mathbf{B})$ The expression of phosphorylated STAT3 of VSMCs induced with AngII. The expression of SOD1 was downregulated with SOD1 siRNA (6 nM). The bottom panels represent quantification of densitometry, expressed as fold increases in phosphorylation, in which the phosphorylation for "scramble siRNA control" was defined as 1.0 ( $n=7$ per group. ${ }^{*} p<0.05^{* *} p<0.01$ n.s.: not significant). (C) The SOD1 activity was pharmacologically inhibited by $0.1 \mathrm{mM}$ DETC (copper-chelating compound). DETC was added to VSMC culture fluid $4 \mathrm{~h}$ before AngII. The bottom panels represent averaged data quantified by densitometry of immunoblots $(n=9$ per group. ${ }^{*} p<0.05 * *<0.01$ n.s.: not significant). (D) The IL-6 levels in the culture fluid were analyzed by the ELISA test $\left(n=12-15\right.$ per group. $\left.{ }^{*} p<0.05\right)$. (E) The expression of phosphorylated STAT3 of VSMCs induced with IL-5. The expression of SOD1 was downregulated with SOD1 siRNA (6 nM). The bottom panels represent quantification of densitometry, expressed as fold increases in phosphorylation, in which the phosphorylation for "scramble siRNA control" was defined as 1.0 ( $n=7$ per group. ${ }^{*} p<0.05^{* *} p<0.01$ n.s.: not significant) $(\mathbf{F})$ The top panels are representative immunoblots of Ang II-induced phosphorylation of STAT3 in the presence and absence of PEGcatalase (100-1000 U). The bottom panels represent averaged data quantified by densitometry of immunoblots $\left(n=3\right.$ per group. $\left.{ }^{* *} p<0.01{ }^{* * *} p<0.001\right)$. Error bars represent SEM. Ang II: angiotensin II; STAT3: signal transducer and activator of transcription 3; GAPDH: glyceraldehyde-3-phosphate dehydrogenase; SOD1: superoxide dismutase 1; DETC: diethyldithiocarbamate; AngII: angiotensin II; PEG-catalase: polyethylene glycol-conjugated catalase.

The effect of AngII has been observed to be polymorphic, with some tyrosinephosphorylated proteins being phosphorylated more rapidly by AngII [33]. On the other hand, it took $24 \mathrm{~h}$ to phosphorylate STAT3 by AngII. The phosphorylation of STAT3 was blunted by SOD1 downregulation and SOD1 inhibitor, suggesting that the phosphorylation of STAT3 by AngII involves the generation of intermediates, which may be affected by SOD1. The in vivo study suggested that IL- 6 was one of the intermediates. IL-6 levels in the culture fluid were increased by AngII in control VSMCs, but not in SOD1 siRNA-treated VSMCs (Figure 6D). In other words, the secretion of IL-6 by AngII was decreased in VSMCs with reduced expression of SOD1.

Next, we directly administered IL-6 (1 ng/mL) to the VSMCs and examined the phosphorylation of STAT3 by western blot analysis. With down-regulation of SOD1, STAT3 phosphorylation due to incubation with IL-6 was blunted (Figure 6E). These results suggest that SOD1 is involved in IL-6 secretion from VSMCs and phosphorylation of STAT3 by IL-6 in the presence of AngII.

SOD1 produces $\mathrm{H}_{2} \mathrm{O}_{2}$ and $\mathrm{O}_{2}$ from two $\mathrm{O}_{2} \cdot{ }^{-}$in the cytoplasm. The effect of SOD1 observed above can be considered as a result of the change in the cytoplasmic $\mathrm{H}_{2} \mathrm{O}_{2}$ concentration. Catalase is an enzyme that metabolizes $\mathrm{H}_{2} \mathrm{O}_{2}$, and since $\mathrm{H}_{2} \mathrm{O}_{2}$ can freely pass through the cell membrane, the addition of catalase extracellularly decreases the intracellular $\mathrm{H}_{2} \mathrm{O}_{2}$ level. Therefore, we administered catalase into the culture medium $24 \mathrm{~h}$ before AngII administration and measured the expression of phosphorylated STAT3 in VSMCs. The administration of catalase (1000 U) attenuated the phosphorylation of STAT3 (Figure 6F).

\section{Discussion}

In this study, we examined the role of SOD1 in vascular physiology and pathophysiology using a well-characterized SOD1 knockout mouse, in particular focusing on aortic hypertrophy and inflammation. We found that knocking out SOD1 alone did not cause hypertension or aortic pathology, going against the common belief that SOD1 has an antioxidant role. Moreover, in the Ang II infusion model, deletion of SOD1 reduced vascular pathology despite a similar increase in blood pressure as in WT. Serum IL-6 levels were increased to a similar extent but the up-regulation in aortic expression of IL-6 mRNA under AngII infusion was markedly blunted in SOD1 $1^{-/}$mice. The phosphorylation of STAT3, 
which involves downstream signaling of IL-6, was also blunted in SOD1 ${ }^{-/-}$mice. Real time-PCR indicated that the AngII-induced up-regulation of NOX2 and the inflammationrelated cytokines (IL-1 $\beta, \mathrm{IL}-6$, and MCP-1) was decreased in the aorta from SOD1 ${ }^{-/}$mice. In VSMCs cultured with AngII, inhibition of SOD1 by siRNA or inhibitor suppressed IL-6 secretion, reduced the effect of IL-6 itself, and suppressed the inflammatory STAT3 cascade. PEG-catalase also inhibited STAT3 phosphorylation in the presence of AngII.

\subsection{SOD1 Changed ROS Levels}

SOD1 is mainly localized in the cytosol and mitochondrial intermembrane spaces. We postulated that intracellular $\mathrm{O}_{2}{ }^{--}$would be upregulated and $\mathrm{H}_{2} \mathrm{O}_{2}$ would be downregulated in SOD1 ${ }^{-/-}$mice aortas both under physiological conditions and under AngII infusion. However, under physiological conditions, cytosolic $\mathrm{O}_{2}{ }^{--}$levels detected by DHE staining and $\mathrm{H}_{2} \mathrm{O}_{2}$ levels estimated from the GSSG/GSH ratio were not different in both mice. On the other hand, it has been reported that $\mathrm{O}_{2}{ }^{-}{ }^{-}$levels detected by lucigenin and DHE staining in SOD1 $1^{-/-}$mice are higher than in WT mice under physiological conditions [24]. One possible reason for this discrepancy is that we used relatively young mice. In this regard, it has been reported that $\mathrm{O}_{2}{ }^{-{ }^{-}}$levels in blood vessels are high in old subjects [41], and $\mathrm{O}_{2}{ }^{--}$is mainly produced in mitochondria, it is possible that the $\mathrm{O}_{2}{ }^{--}$ produced in the young cells was rapidly degraded by SOD2, and there was less $\mathrm{O}_{2}{ }^{--}$ leaking into the cytoplasm itself. In AngII-treated mice, the GSSG/GSH ratio in the aorta was increased and DHE staining was enhanced in both mice, but the differences were not significant. On the other hand, in RBCs that lack SOD2, the GSSG/GSH ratio, i.e., the increase in $\mathrm{H}_{2} \mathrm{O}_{2}$, was attenuated in SOD1 ${ }^{-/-}$mice by Ang II treatment. This suggests that the presence of SOD2 compensated for the effect of SOD1 deficiency in the cells of the aortas as a whole, and that the change in ROS in the whole vessel might be masked. Since some reactive thiols on proteins (such as small GTPase Ras, phosphatases and so on) are susceptible to $\mathrm{H}_{2} \mathrm{O}_{2}$ (hydroxyl radical) [42-44]. Thus, relatively small changes in $\mathrm{H}_{2} \mathrm{O}_{2}$ which may not be detected by GSSG/GSH in cytosol, could have significant effects on local signaling molecules related to hypertrophy in VSMCs.

Real-time PCR showed that NOX2 was not upregulated in the presence of AngII in $\mathrm{SOD}^{-1-}$ mice, suggesting that aortic local $\mathrm{O}_{2}{ }^{--}$production was also reduced by SOD1 deficiency. However, ROSs detected by DHE staining was no difference between WT and SOD1 ${ }^{-1-}$ mice (Supplemental Figure S2). Thus, the contribution of NOX2 to overall aortic ROS production may be limited. One of the mechanisms for the reduced expression of NOX2 in SOD1 $1^{-/-}$may be due to the molecular interaction between NOX2 and STAT3 [45]. Extracellular $\mathrm{H}_{2} \mathrm{O}_{2}$ levels in serum were detected using d-ROMs. There were similar increases in serum d-ROM levels due to AngII infusion in SOD1 ${ }^{-/-}$and WT mice, suggesting that $\mathrm{SOD} 3$ catalyzed $\mathrm{O}_{2}{ }^{--}$to an equal extent.

\subsection{Hypertensive Response}

AngII behaves as a vasopressor hormone via $G$ protein-mediated pathways [4]. In addition, AngII post-translationally activates multiple NOX isoforms (NOX1, NOX2, and NOX5), and in the later phase, it also up-regulates the expressions of NOX enzymes [46]. By means of these mechanisms, AngII produces $\mathrm{O}_{2}{ }^{\cdot-}$, which decreases the bioavailability of $\mathrm{NO}$ and induces hypertension. $\mathrm{O}_{2}{ }^{--}$is rapidly catalyzed to $\mathrm{H}_{2} \mathrm{O}_{2}$ by SOD [14]. Furthermore, cytosol $\mathrm{H}_{2} \mathrm{O}_{2}$ has been assumed to act as a vasodilator known as an endothelium-derived hyperpolarizing factor (EDHF) [47].

The role of SOD in the hypertensive response may vary with its individual isoforms as well as their localization. For example, in extracellular SOD (SOD3)-deficient mice, the AngII-induced hypertensive response was enhanced [48] and brain SOD3 was especially important in blood pressure modulation $[49,50]$. In addition, adenovirus-mediated gene transfer of SOD3 decreased blood pressure and improved endothelium-dependent relaxation in the spontaneous hypertensive rat [51]. The findings of these studies clearly 
indicated that SOD3 reduces the hypertensive response and that the elimination of extracellular $\mathrm{O}_{2} \cdot-$ by SOD3 is important to the bioavailability of $\mathrm{NO}$ and blood pressure.

SOD1 is localized in the cytosol and mitochondrial intermembrane spaces and its role in the pressor response is complex and controversial; one study suggested that SOD1 had no remarkable role in blood pressure in the presence of AngII [20] and others suggested that it had anti-hypertensive roles [21-23]. There was also a discrepancy in basal blood pressures [20-23]. These previous inconsistent results suggest that the modulation of blood pressure by SOD1 might depend on age, methods of inducing hypertension, and study settings. One difference, in conclusion, may have resulted from employing SOD1 transgenic or SOD1 $1^{-/-}$mice. The Ang II dose was varied depending on study design $(0.4-5 \mathrm{mg} / \mathrm{kg} /$ day $7-14$ days) [23,52-55]. In the present study, we aimed to evaluate aortic remodeling and used a relatively high concentration of AngII ( $3.2 \mathrm{mg} / \mathrm{kg} /$ day) in SOD1 $1^{-/-}$ mice as in previous studies [22] but no difference in $\mathrm{O}_{2}{ }^{--}$level was observed as described above. Our results showed there was no difference in basal blood pressure and a similar increase was observed in the presence of AngII for seven days.

Some studies used radiotelemetry to measure blood pressure, however, we used the noninvasive tail-cuff method as previously $[20,22,26]$. To reduce the stress associated with the BP measurements and variations, mice were introduced into the plastic restrainer for about $30 \mathrm{~min}$ from one week before the main experiment and 10 times averages were calculated at each determination. The non-invasive method to measure blood pressure has been reported to correlate well with intra-arterial measurements [56].

\subsection{Aortic Remodeling}

Some studies have shown that SOD1 ${ }^{-/-}$mice exhibit baseline vascular hypertrophy in cerebral arterioles and renal afferent arterioles [21,23]. We did not investigate arterioles but observed that the baseline aortic thickness of SOD1 ${ }^{-/}$mice was similar to that of WT mice. In our study, $\mathrm{SOD1}^{-/-}$mice revealed less aortic hypertrophy under AngII infusion in spite of similar pressor responses. Wang et al. reported that in mice overexpressing human SOD1, the aortic wall thickened to the same extent as in WT mice, even though the Ang II-induced pressure increase response was attenuated [22]. From this study and ours, we found that the presence of SOD1 promoted aortic remodeling in response to AngII administration, and the degree of remodeling was at least partially independent of the AngII-induced pressure-raising response.

In vitro studies have shown that ROS induced by AngII plays an important role in VSMC hypertrophy $[4,9,10,17,18,57]$. Many studies have also shown that intracellular $\mathrm{H}_{2} \mathrm{O}_{2}$ production is an important mediator of protein synthesis in VSMCs in vitro [15,16]. In an in vivo study, NOX promoted aortic hypertrophy in a hypertensive model infused with AngII, while medial hypertrophy was reduced in NOX2-deficient mice [26]. Zhang et al. reported that in VSMCs specific catalase overexpression mice, Ang II-induced aortic hypertrophy was attenuated in spite of a similar hypertensive response with control mice [58]. These studies are consistent with our hypothesis that $\mathrm{O}_{2}{ }^{--}$produced by Ang II is metabolized to cytosolic $\mathrm{H}_{2} \mathrm{O}_{2}$ in the presence of SOD1, and that this $\mathrm{H}_{2} \mathrm{O}_{2}$ causes VSMC hypertrophy, leading to aortic thickening in vivo.

AngII is a multifunction hormone, and activates a complex series of intracellular signaling pathways for VSMC growth and proliferation [33], including extracellular signalregulated kinase 1/2 (ERK1/2), p38 mitogen-activated protein (MAP) kinases, Akt, c-jun N-terminal kinases, Rho kinases, Ras and Janus kinase2/Signal transducer and activator of transcription 3 (JAK2/STAT3) pathways [4,59,60]. Mitogen-activated protein kinases, including ERK1/2, have been implicated in VSMC differentiation, migration, and proliferation. Moreover, the cell survival protein kinase, Akt/protein kinase B, has been seen to be involved in AngII induced protein synthesis and AngII is known to activate Akt via the production of $\mathrm{H}_{2} \mathrm{O}_{2}$ from NOX in vitro [34,37]. However, in our in vivo study, the phosphorylation of ERK1/2 and Akt was not enhanced by AngII-infusion at seven days. Although we cannot rule out the possibility that these kinases are transiently activated at 
earlier stages, we did not think that they played an important role in our in vivo aortic remodeling model. Therefore, we examined other AngII-related kinases that are constantly suppressed by SOD1 deletion after seven days of AngII treatment.

AngII promotes the inflammatory JAK/STAT pathway [61]. In other studies, the JAK/STAT pathway responded to intracellular $\mathrm{H}_{2} \mathrm{O}_{2}$ generation [53,62], and AngII-induced activation of the JAK2/STAT3 pathway required NOX systems [38]. Therefore, we investigated whether the JAK2/STAT3 pathway is involved in the aorta used in the study. AngII-infusion had enhanced the phosphorylation of STAT3 in the aortas of WT mice at seven days, and interestingly, this was blunted in SOD1 ${ }^{-/}$mice. Marrero et al. reported that activation of STAT3 by AngII was observed after $60 \mathrm{~min}$ [35] and therefore, AngIIinduced STAT3 activation might be mediated by autocrine/paracrine mechanisms. We examined mechanisms further in cultured VSMCs. Consistent with their study, we could not detect enhanced phosphorylation of STAT3 in VSMCs incubated with AngII within a short period, but phosphorylation was enhanced after $24 \mathrm{~h}$. The slow phosphorylation of STAT3 was blunted by genetic and pharmacological inhibition of SOD1 and by PEGcatalase. These findings suggested that AngII activates STAT3 in an autocrine/paracrine manner and that the response requires $\mathrm{H}_{2} \mathrm{O}_{2}$ generation by SOD1, leading to aortic hypertrophy. Cheng JF et al. reported that AngII induces proliferation of aortic VSMCs through activation of the JAK2/STAT3 signaling pathway [63], which is consistent with our findings.

\subsection{Inflammation and IL-6 Production}

Many cytokines and growth factors activate the JAK2/STAT3 pathway, and IL-6 is representative of such cytokines. Previous studies have indicated that AngII induced IL-6 synthesis in VSMCs as well as its release from them, and these processes required ROS generated by NOX systems [38-40]. We considered that IL-6 is one of the intermediate substances that activates STAT3 under Ang II administration in the present study. In the presence of AngII, elevations of serum IL-6 levels were similar in both WT mice and SOD1 $1^{-/-}$mice, whereas the up-regulation of aortic IL-6 RNA expression was blunted in SOD1 ${ }^{-1-}$ mice. Under AngII infusion, the aortic expressions of other cytokines, such as MCP-1 and IL- $1 \beta$ were also increased but were blunted in SOD1 $1^{-/-}$mice. In a study using cultured VSMCs, AngII had increased IL-6 release into the culture fluid in control VSMCs at $24 \mathrm{~h}$, however, the release of IL-6 was reduced in VSMCs in which SOD1 was down-regulated. The rapid phosphorylation of STAT3 due to IL-6 seen at 5 min was also blunted in VSMCs with down-regulated SOD1. These results indicate that SOD1 was necessary to induce the synthesis and secretion of IL-6 and that it also enhanced the phosphorylation of STAT3 (Figure 7). We considered that SOD1 in aortic smooth muscle promoted inflammatory remodeling under AngII infusion via cytosolic $\mathrm{H}_{2} \mathrm{O}_{2}$ production and modulation of IL-6/STAT3 signaling.

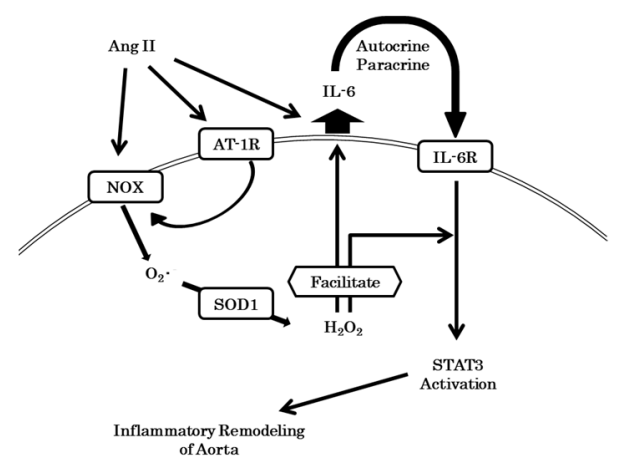

Figure 7. The cytosolic $\mathrm{H}_{2} \mathrm{O}_{2}$ produced by SOD1 facilitated IL-6 synthesis in VSMCs and its secretion from them, which had been induced by AngII. $\mathrm{H}_{2} \mathrm{O}_{2}$ facilitated the activation of STAT3 by IL- 6 . These mechanisms were responsible for the inflammatory remodeling of aortas. AT-1R: angiotensin II receptor 1; NOX: NADPH oxidase. 
In previous studies using IL-6 deficient mice, aortic $\mathrm{O}_{2}{ }^{--}$production induced by AngII was blunted [64] and AngII-induced retinal vascular hypertrophy/remodeling was suppressed [52]. AngII induced the production of IL-6, which mediated remodeling/hypertrophy in vascular cells $[54,55]$ and cardiomyocytes [65] in an autocrine/paracrine manner. Together, our results and these previous findings indicate that there would be close interactions between AngII induced ROS generation and inflammation-related cytokines, especially IL-6. It is known that innate and acquired immune cells are involved in one mechanism of hypertension [66]. In hypertensive blood vessels, immune cells not only produce ROS, but also promote ROS production from vascular cells by cytokines produced, which plays a role in vascular damage in hypertension [67]. It is possible that IL-6 secretion and ROS in immune cells are also regulated by SOD1 and may affect blood pressure and aortic remodeling.

As $\mathrm{H}_{2} \mathrm{O}_{2}$ has been reported to modulate many transcription factors, kinases, small GTPases, and phosphatases, these molecules might be involved in the modulation of IL-6 production and STAT3 activation due to IL-6. For example, transcription of IL-6 depends on NF-kappa B activation [68] and $\mathrm{H}_{2} \mathrm{O}_{2}$ can activate NF-kappa $\mathrm{B}$ although the mechanism has not been completely clarified [69,70]. $\mathrm{H}_{2} \mathrm{O}_{2}$ attacks the cysteine thiol of $\mathrm{SH} 2$ containing phosphatase (SHP), which is in the active center, and inhibits SHP activity [71-73]. The decreased cytosolic $\mathrm{H}_{2} \mathrm{O}_{2}$ production through deletion of SOD1 in VSMCs might activate SHP and dephosphorylate and inhibit the JAK/STAT pathway. Further studies will be required to clarify precise mechanisms for IL-6 production and STAT3 activation due to AngII in a SOD1-dependent manner.

\section{Conclusions}

In conclusion, by comparing SOD1 ${ }^{-/-}$with WT mice, we found that SOD1 function in the vasculature is limited under physiological conditions, but in the presence of Ang II, it causes aortic hypertrophy independent of the pressure increase response. Because of the presence of mitochondria in vascular cells, it was inferred that SOD2 compensated for SOD1 deficiency, and no changes in net ROS were observed in the aorta as a whole. However, the elevation of cytoplasmic local $\mathrm{H}_{2} \mathrm{O}_{2}$ produced by SOD1 was thought to cause aortic hypertrophy by targeting signaling molecules such as Ras and phosphatases [42-44] via secretion of IL- 6 and activation of inflammatory STAT3 in VSMCs. These results suggest that SOD1 is involved in aortic remodeling in Ang II-induced hypertension via regulation of the inflammatory pathway IL-6/STAT3 axis in VSMCs.

Supplementary Materials: The following are available online at https:/ /www.mdpi.com/2076-3 921/10/3/471/s1, Figure S1: Microscopic appearance of aortic rings, Figure S2: Appearance and quantitative analysis of DHE staining of the aorta, Figure S3: Serum TNF- $\alpha$ concentration and TNF- $\alpha$, NOX1, and NOX4 mRNA expression in aortas.

Author Contributions: Conceptualization, Y.S., and T.A.; methodology, Y.S., N.I., and T.A.; resources, Y.S. and T.A.; data curation, Y.S., N.I., T.K., A.S. and T.A.; writing-original draft preparation, Y.S.; writing-review and editing, M.F., Y.I., and T.A.; funding acquisition, Y.S. and T.A. All authors have read and agreed to the published version of the manuscript.

Funding: This work was supported in part by a grant from the Ministry of Defense and the Research Fund of the Mitsukoshi Health and Welfare Foundation and by the JSPS KAKENHI Grant Number JP20K17204 to Y.S.

Institutional Review Board Statement: All experimental protocols were approved by National Defense Medical College Board for Studies in Experimental Animals (approval number: 10063).

Informed Consent Statement: Not applicable.

Data Availability Statement: The data presented in this study are available from the corresponding author on reasonable request. 
Acknowledgments: We would like to thank the members of our animal institute for their assistance with animal care and those of the Central Research Laboratory of the National Defense Medical College for pathological assistance. We also thank Azusa Onodera and Miyuki Hama (Department of Internal Medicine, National Defense Medical College) for technical support.

Conflicts of Interest: All the authors declare that they have no conflicts of interest.

\section{References}

1. Li, Z.; Xu, X.; Leng, X.; He, M.; Wang, J.; Cheng, S.; Wu, H. Roles of reactive oxygen species in cell signaling pathways and immune responses to viral infections. Arch. Virol. 2017, 162, 603-610. [CrossRef]

2. Finkel, T. Oxygen radicals and signaling. Curr. Opin. Cell Biol. 1998, 10, 248-253. [CrossRef]

3. Burton, G.J.; Jauniaux, E. Oxidative stress. Best Pract. Res. Clin. Obstet. Gynaecol. 2011, 25, 287-299. [CrossRef]

4. Mehta, P.K.; Griendling, K.K. Angiotensin II cell signaling: Physiological and pathological effects in the cardiovascular system. Am. J. Physiol. Cell Physiol. 2007, 292, C82-C97. [CrossRef]

5. Nguyen, D.C.A.; Montezano, A.C.; Burger, D.; Touyz, R.M. Angiotensin II, NADPH oxidase, and redox signaling in the vasculature. Antioxid. Redox Signal. 2013, 19, 1110-1120. [CrossRef] [PubMed]

6. Seshiah, P.N.; Weber, D.S.; Rocic, P.; Valppu, L.; Taniyama, Y.; Griendling, K.K. Angiotensin II stimulation of NAD(P)H oxidase activity: Upstream mediators. Circ. Res. 2002, 91, 406-413. [CrossRef] [PubMed]

7. Touyz, R.M.; Yao, G.; Schiffrin, E.L. c-Src induces phosphorylation and translocation of p47phox: Role in superoxide generation by angiotensin II in human vascular smooth muscle cells. Arterioscler. Thromb. Vasc. Biol. 2003, 23, 981-987. [CrossRef]

8. Touyz, R.M.; Chen, X.; Tabet, F.; Yao, G.; He, G.; Quinn, M.T.; Pagano, P.J.; Schiffrin, E.L. Expression of a functionally active gp91phox-containing neutrophil-type NAD $(\mathrm{P}) \mathrm{H}$ oxidase in smooth muscle cells from human resistance arteries: Regulation by angiotensin II. Circ. Res. 2002, 90, 1205-1213. [CrossRef] [PubMed]

9. Griendling, K.K.; Minieri, C.A.; Ollerenshaw, J.D.; Alexander, R.W. Angiotensin II stimulates NADH and NADPH oxidase activity in cultured vascular smooth muscle cells. Circ. Res. 1994, 74, 1141-1148. [CrossRef] [PubMed]

10. Ushio-Fukai, M.; Zafari, A.M.; Fukui, T.; Ishizaka, N.; Griendling, K.K. p22phox is a critical component of the superoxidegenerating NADH/NADPH oxidase system and regulates angiotensin II-induced hypertrophy in vascular smooth muscle cells. J. Biol. Chem. 1996, 271, 23317-23321. [CrossRef]

11. Ushio-Fukai, M. Localizing NADPH oxidase-derived ROS. Sci. STKE 2006, 2006, re8. [CrossRef] [PubMed]

12. Miller, F.J., Jr.; Filali, M.; Huss, G.J.; Stanic, B.; Chamseddine, A.; Barna, T.J.; Lamb, F.S. Cytokine activation of nuclear factor kappa B in vascular smooth muscle cells requires signaling endosomes containing Nox1 and ClC-3. Circ. Res. 2007, 101, 663-671. [CrossRef]

13. Chovanová, K.; Böhmer, M.; Poljovka, A.; Budiš, J.; Harichová, J.; Szemeš, T.; Zámocký, M. Parallel molecular evolution of catalases and superoxide dismutases-Focus on thermophilic fungal genomes. Antioxidants 2020, 9, 1047. [CrossRef] [PubMed]

14. Fukai, T.; Ushio-Fukai, M. Superoxide dismutases: Role in redox signaling, vascular function, and diseases. Antioxid. Redox Signal 2011, 15, 1583-1606. [CrossRef] [PubMed]

15. Zafari, A.M.; Ushio-Fukai, M.; Akers, M.; Yin, Q.; Shah, A.; Harrison, D.G.; Taylor, W.R.; Griendling, K.K. Role of NADH/NADPH oxidase-derived $\mathrm{H}_{2} \mathrm{O}_{2}$ in angiotensin II-induced vascular hypertrophy. Hypertension 1998, 32, 488-495. [CrossRef]

16. Rao, G.N.; Berk, B.C. Active oxygen species stimulate vascular smooth muscle cell growth and proto-oncogene expression. Circ. Res. 1992, 70, 593-599. [CrossRef] [PubMed]

17. Berk, B.C.; Vekshtein, V.; Gordon, H.M.; Tsuda, T. Angiotensin II-stimulated protein synthesis in cultured vascular smooth muscle cells. Hypertension 1989, 13, 305-314. [CrossRef]

18. Geisterfer, A.A.; Peach, M.J.; Owens, G.K. Angiotensin II induces hypertrophy, not hyperplasia, of cultured rat aortic smooth muscle cells. Circ. Res. 1988, 62, 749-756. [CrossRef]

19. Miller, A.F. Superoxide dismutases: Ancient enzymes and new insights. FEBS Lett. 2012, 586, 585-595. [CrossRef]

20. Wakisaka, Y.; Chu, Y.; Miller, J.D.; Rosenberg, G.A.; Heistad, D.D. Critical role for copper/zinc-superoxide dismutase in preventing spontaneous intracerebral hemorrhage during acute and chronic hypertension in mice. Stroke 2010, 41, 790-797. [CrossRef]

21. Baumbach, G.L.; Didion, S.P.; Faraci, F.M. Hypertrophy of cerebral arterioles in mice deficient in expression of the gene for CuZn superoxide dismutase. Stroke 2006, 37, 1850-1855. [CrossRef]

22. Wang, H.D.; Johns, D.G.; Xu, S.; Cohen, R.A. Role of superoxide anion in regulating pressor and vascular hypertrophic response to angiotensin II. Am. J. Physiol. Heart Circ. Physiol. 2002, 282, H1697-H1702. [CrossRef] [PubMed]

23. Carlstrom, M.; Lai, E.Y.; Ma, Z.; Steege, A.; Patzak, A.; Eriksson, U.J.; Lundberg, J.O.; Wilcox, C.S.; Persson, A.E. Superoxide dismutase 1 limits renal microvascular remodeling and attenuates arteriole and blood pressure responses to angiotensin II via modulation of nitric oxide bioavailability. Hypertension 2010, 56, 907-913. [CrossRef] [PubMed]

24. Didion, S.P.; Ryan, M.J.; Didion, L.A.; Fegan, P.E.; Sigmund, C.D.; Faraci, F.M. Increased superoxide and vascular dysfunction in CuZnSOD-deficient mice. Circ. Res. 2002, 91, 938-944. [CrossRef] [PubMed]

25. Ishigami, N.; Isoda, K.; Adachi, T.; Niida, T.; Kujiraoka, T.; Hakuno, D.; Kondo, H.; Kusuhara, M.; Ohsuzu, F. Deficiency of CuZn superoxide dismutase promotes inflammation and alters medial structure following vascular injury. J. Atheroscler. Thromb. 2018, 18, 1009-1017. [CrossRef] [PubMed] 
26. Wang, H.D.; Xu, S.; Johns, D.G.; Du, Y.; Quinn, M.T.; Cayatte, A.J.; Cohen, R.A. Role of NADPH oxidase in the vascular hypertrophic and oxidative stress response to angiotensin II in mice. Circ. Res. 2001, 88, 947-953. [CrossRef] [PubMed]

27. Costa, S.A.; Tzanov, T.; Filipa Carneiro, A.; Paar, A.; Gübitz, G.M.; Cavaco-Paulo, A. Studies of stabilization of native catalase using additives. Enzym. Microb. Technol. 2002, 30, 387-391. [CrossRef]

28. Beauchamp, C.; Fridovich, I. Superoxide dismutase: Improved assays and an assay applicable to acrylamide gels. Anal. Biochem. 1971, 44, 276-287. [CrossRef]

29. Endo, J.; Sano, M.; Katayama, T.; Hishiki, T.; Shinmura, K.; Morizane, S.; Matsuhashi, T.; Katsumata, Y.; Zhang, Y.; Ito, H.; et al. Metabolic remodeling induced by mitochondrial aldehyde stress stimulates tolerance to oxidative stress in the heart. Circ. Res. 2009, 105, 1118-1127. [CrossRef]

30. Vassalle, C.; Boni, C.; Di Cecco, P.; Ndreu, R.; Zucchelli, G.C. Automation and validation of a fast method for the assessment of in vivo oxidative stress levels. Clin. Chem. Lab. Med. 2006, 44, 1372-1375. [CrossRef]

31. Cornelli, U.; Terranova, R.; Luca, S.; Cornelli, M.; Alberti, A. Bioavailability and antioxidant activity of some food supplements in men and women using the D-Roms test as a marker of oxidative stress. J. Nutr. 2001, 131, 3208-3211. [CrossRef] [PubMed]

32. Tavender, T.J.; Bulleid, N.J. Peroxiredoxin IV protects cells from oxidative stress by removing $\mathrm{H}_{2} \mathrm{O}_{2}$ produced during disulphide formation. J. Cell Sci. 2010, 123, 2672-2679. [CrossRef] [PubMed]

33. Griendling, K.K.; Ushio-Fukai, M.; Lassegue, B.; Alexander, R.W. Angiotensin II signaling in vascular smooth muscle. New concepts. Hypertension 1997, 29, 366-373. [CrossRef]

34. Ushio-Fukai, M.; Alexander, R.W.; Akers, M.; Yin, Q.; Fujio, Y.; Walsh, K.; Griendling, K.K. Reactive oxygen species mediate the activation of Akt/protein kinase B by angiotensin II in vascular smooth muscle cells. J. Biol. Chem. 1999, 274, 22699-22704. [CrossRef]

35. Marrero, M.B.; Schieffer, B.; Paxton, W.G.; Heerdt, L.; Berk, B.C.; Delafontaine, P.; Bernstein, K.E. Direct stimulation of Jak/STAT pathway by the angiotensin II AT1 receptor. Nature 1995, 375, 247-250. [CrossRef]

36. Eguchi, S.; Matsumoto, T.; Motley, E.D.; Utsunomiya, H.; Inagami, T. Identification of an essential signaling cascade for mitogenactivated protein kinase activation by angiotensin II in cultured rat vascular smooth muscle cells. Possible requirement of Gq-mediated p21ras activation coupled to a Ca ${ }^{2+} /$ calmodulin-sensitive tyrosine kinase. J. Biol. Chem. 1996, $271,14169-14175$.

37. Taniyama, Y.; Ushio-Fukai, M.; Hitomi, H.; Rocic, P.; Kingsley, M.J.; Pfahnl, C.; Weber, D.S.; Alexander, R.W.; Griendling, K.K. Role of p38 MAPK and MAPKAPK-2 in angiotensin II-induced Akt activation in vascular smooth muscle cells. Am. J. Physiol. Cell Physiol. 2004, 287, C494-C499. [CrossRef]

38. Schieffer, B.; Luchtefeld, M.; Braun, S.; Hilfiker, A.; Hilfiker-Kleiner, D.; Drexler, H. Role of NAD(P)H oxidase in angiotensin II-induced JAK/STAT signaling and cytokine induction. Circ. Res. 2000, 87, 1195-1201. [CrossRef] [PubMed]

39. Schieffer, B.; Schieffer, E.; Hilfiker-Kleiner, D.; Hilfiker, A.; Kovanen, P.T.; Kaartinen, M.; Nussberger, J.; Harringer, W.; Drexler, H. Expression of angiotensin II and interleukin 6 in human coronary atherosclerotic plaques: Potential implications for inflammation and plaque instability. Circulation 2000, 101, 1372-1378. [CrossRef] [PubMed]

40. Kranzhofer, R.; Schmidt, J.; Pfeiffer, C.A.; Hagl, S.; Libby, P.; Kubler, W. Angiotensin induces inflammatory activation of human vascular smooth muscle cells. Arterioscler. Thromb. Vasc. Biol. 1999, 19, 1623-1629. [CrossRef]

41. Park, S.Y.; Ives, S.J.; Gifford, J.R.; Andtbacka, R.H.; Hyngstrom, J.R.; Reese, V.; Layec, G.; Bharath, L.P.; Symons, J.D.; Richardson, R.S. Impact of age on the vasodilatory function of human skeletal muscle feed arteries. Am. J. Physiol. Heart Circ. Physiol. 2016, 310, H217-H225. [CrossRef]

42. Hobbs, G.A.; Zhou, B.; Cox, A.D.; Campbell, S.L. Rho GTPases, oxidation, and cell redox control. Small GTPases 2014, 5, e28579. [CrossRef]

43. Tonks, N.K. Redox redux: Revisiting PTPs and the control of cell signaling. Cell 2005, 121, 667-670. [CrossRef]

44. Rao, R.K.; Clayton, L.W. Regulation of protein phosphatase 2A by hydrogen peroxide and glutathionylation. Biochem. Biophys. Res. Commun. 2002, 293, 610-616. [CrossRef]

45. Manea, S.-A.; Constantin, A.; Manda, G.; Sasson, S.; Manea, A. Regulation of Nox enzymes expression in vascular pathophysiology: Focusing on transcription factors and epigenetic mechanisms. Redox Biol. 2015, 5, 358-366. [CrossRef] [PubMed]

46. Garrido, A.M.; Griendling, K.K. NADPH oxidases and angiotensin II receptor signaling. Mol. Cell Endocrinol. 2009, 302, 148-158. [CrossRef] [PubMed]

47. Morikawa, K.; Shimokawa, H.; Matoba, T.; Kubota, H.; Akaike, T.; Talukder, M.A.; Hatanaka, M.; Fujiki, T.; Maeda, H.; Takahashi, S.; et al. Pivotal role of $\mathrm{Cu}, \mathrm{Zn}$-superoxide dismutase in endothelium-dependent hyperpolarization. J. Clin. Investig. 2003, 112, 1871-1879. [CrossRef] [PubMed]

48. Gongora, M.C.; Qin, Z.; Laude, K.; Kim, H.W.; McCann, L.; Folz, J.R.; Dikalov, S.; Fukai, T.; Harrison, D.G. Role of extracellular superoxide dismutase in hypertension. Hypertension 2006, 48, 473-481. [CrossRef]

49. Lob, H.E.; Vinh, A.; Li, L.; Blinder, Y.; Offermanns, S.; Harrison, D.G. Role of vascular extracellular superoxide dismutase in hypertension. Hypertension 2011, 58, 232-239. [CrossRef] [PubMed]

50. Lob, H.E.; Marvar, P.J.; Guzik, T.J.; Sharma, S.; McCann, L.A.; Weyand, C.; Gordon, F.J.; Harrison, D.G. Induction of hypertension and peripheral inflammation by reduction of extracellular superoxide dismutase in the central nervous system. Hypertension 2009, 55, 277-283. [CrossRef] [PubMed] 
51. Chu, Y.; Iida, S.; Lund, D.D.; Weiss, R.M.; DiBona, G.F.; Watanabe, Y.; Faraci, F.M.; Heistad, D.D. Gene transfer of extracellular superoxide dismutase reduces arterial pressure in spontaneously hypertensive rats: Role of heparin-binding domain. Circ. Res. 2003, 92, 461-468. [CrossRef] [PubMed]

52. Rojas, M.; Zhang, W.; Lee, D.L.; Romero, M.J.; Nguyen, D.T.; Al-Shabrawey, M.; Tsai, N.T.; Liou, G.I.; Brands, M.W.; Caldwell, R.W.; et al. Role of IL-6 in angiotensin II-induced retinal vascular inflammation. Investig. Ophthalmol. Vis. Sci. 2010, 51, 1709-1718. [CrossRef]

53. Simon, A.R.; Rai, U.; Fanburg, B.L.; Cochran, B.H. Activation of the JAK-STAT pathway by reactive oxygen species. Am. J. Physiol. 1998, 275, C1640-C1652. [CrossRef]

54. Tieu, B.C.; Ju, X.; Lee, C.; Sun, H.; Lejeune, W.; Recinos, A., 3rd; Brasier, A.R.; Tilton, R.G. Aortic adventitial fibroblasts participate in angiotensin-induced vascular wall inflammation and remodeling. J. Vasc. Res. 2011, 8, 261-272. [CrossRef]

55. Tieu, B.C.; Lee, C.; Sun, H.; Lejeune, W.; Recinos, A., 3rd; Ju, X.; Spratt, H.; Guo, D.C.; Milewicz, D.; Tilton, R.G.; et al. An adventitial IL-6/MCP1 amplification loop accelerates macrophage-mediated vascular inflammation leading to aortic dissection in mice. J. Clin. Investig. 2009, 119, 3637-3651. [CrossRef]

56. Johns, C.; Gavras, I.; Handy, D.E.; Salomao, A.; Gavras, H. Models of experimental hypertension in mice. Hypertension 1996, 28 , 1064-1069. [CrossRef]

57. Burdon, R.H. Superoxide and hydrogen peroxide in relation to mammalian cell proliferation. Free Radic. Biol. Med. 1995, 18, 775-794. [CrossRef]

58. Zhang, Y.; Griendling, K.K.; Dikalova, A.; Owens, G.K.; Taylor, W.R. Vascular hypertrophy in angiotensin II-induced hypertension is mediated by vascular smooth muscle cell-derived $\mathrm{H}_{2} \mathrm{O}_{2}$. Hypertension 2005, 46, 732-737. [CrossRef]

59. Higashi, M.; Shimokawa, H.; Hattori, T.; Hiroki, J.; Mukai, Y.; Morikawa, K.; Ichiki, T.; Takahashi, S.; Takeshita, A. Long-term inhibition of Rho-kinase suppresses angiotensin II-induced cardiovascular hypertrophy in rats in vivo: Effect on endothelial NAD(P)H oxidase system. Circ. Res. 2003, 93, 767-775. [CrossRef]

60. Adachi, T.; Pimentel, D.R.; Heibeck, T.; Hou, X.; Lee, Y.J.; Jiang, B.; Ido, Y.; Cohen, R.A. S-glutathiolation of Ras mediates redox-sensitive signaling by angiotensin II in vascular smooth muscle cells. J. Biol. Chem. 2004, 279, 29857-29862. [CrossRef]

61. Frank, G.D.; Saito, S.; Motley, E.D.; Sasaki, T.; Ohba, M.; Kuroki, T.; Inagami, T.; Eguchi, S. Requirement of Ca ${ }^{2+}$ and PKCdelta for Janus kinase 2 activation by angiotensin II: Involvement of PYK2. Mol. Endocrinol. 2002, 16, 367-377. [PubMed]

62. Madamanchi, N.R.; Li, S.; Patterson, C.; Runge, M.S. Reactive oxygen species regulate heat-shock protein 70 via the JAK/STAT pathway. Arterioscler. Thromb. Vasc. Biol. 2001, 21, 321-326. [CrossRef]

63. Cheng, J.F.; Ni, G.H.; Chen, M.F.; Li, Y.J.; Wang, Y.J.; Wang, C.L.; Yuan, Q.; Shi, R.Z.; Hu, C.P.; Yang, T.L. Involvement of profilin-1 in angiotensin II-induced vascular smooth muscle cell proliferation. Vasc. Pharmacol. 2011, 55, 34-41. [CrossRef]

64. Schrader, L.I.; Kinzenbaw, D.A.; Johnson, A.W.; Faraci, F.M.; Didion, S.P. IL-6 deficiency protects against angiotensin II induced endothelial dysfunction and hypertrophy. Arterioscler. Thromb. Vasc. Biol. 2007, 27, 2576-2581. [CrossRef]

65. Sano, M.; Fukuda, K.; Kodama, H.; Pan, J.; Saito, M.; Matsuzaki, J.; Takahashi, T.; Makino, S.; Kato, T.; Ogawa, S. Interleukin-6 family of cytokines mediate angiotensin II-induced cardiac hypertrophy in rodent cardiomyocytes. J. Biol. Chem. 2000, 275, 29717-29723. [CrossRef]

66. Norlander, A.E.; Madhur, M.S.; Harrison, D.G. The immunology of hypertension. J. Exp. Med. 2018, 215, 21-33. [CrossRef]

67. McMaster, W.G.; Kirabo, A.; Madhur, M.S.; Harrison, D.G. Inflammation, immunity, and hypertensive end-organ damage. Circ. Res. 2015, 116, 1022-1033. [CrossRef]

68. Libermann, T.A.; Baltimore, D. Activation of interleukin-6 gene expression through the NF-kappa B transcription factor. Mol. Cell. Biol. 1990, 10, 2327-2334. [CrossRef]

69. Schreck, R.; Rieber, P.; Baeuerle, P.A. Reactive oxygen intermediates as apparently widely used messengers in the activation of the NF-kappa B transcription factor and HIV-1. EMBO J. 1991, 10, 2247-2258. [CrossRef]

70. Gloire, G.; Legrand-Poels, S.; Piette, J. NF-kappaB activation by reactive oxygen species: Fifteen years later. Biochem. Pharmacol. 2006, 72, 1493-1505. [CrossRef]

71. Wormald, S.; Hilton, D.J. Inhibitors of cytokine signal transduction. J. Biol. Chem. 2004, 279, 821-824. [CrossRef]

72. Juarez, J.C.; Manuia, M.; Burnett, M.E.; Betancourt, O.; Boivin, B.; Shaw, D.E.; Tonks, N.K.; Mazar, A.P.; Donate, F. Superoxide dismutase 1 (SOD1) is essential for $\mathrm{H}_{2} \mathrm{O}_{2}$-mediated oxidation and inactivation of phosphatases in growth factor signaling. Proc. Natl. Acad. Sci. USA 2008, 105, 7147-7152. [CrossRef] [PubMed]

73. Finkel, T. Signal transduction by reactive oxygen species. J. Cell Biol. 2011, 194, 7-15. [CrossRef] 